\title{
FOREWORD: POLAR ENVIRONMENTS, A CHANGING WORLD
}

E. SERRANO*

Departamento de Geografía. Universidad de Valladolid, Spain.

Received 2 March 2016

Accepted 10 March 2016

*Corresponding author: E. Serrano, Departamento de Geografía. Universidad de Valladolid, Paseo Prado de La Magdalena s/n, 47011 Valladolid, Spain. E-mail: serranoe@fyl.uva.es

The focus of this special issue of Cuadernos de Investigación Geográfica is on polar environments and includes nine papers describing new advances and studies concerning physical geography. This issue deals with periglacial environments, permafrost, glaciers and snow and includes papers on the Arctic (French; Andrés et al.; Navarro et al.; Martín Moreno and Allende; López-Moreno et al.), and the Antarctic (Balks and O'Neill; Hrbáček et al.; López-Martínez et al.; de Pablo et al.). All areas studied are of interest, and some of them have now been studied for 46 years. In all cases the authors have great experience of working in the field. The presence of Spanish research and exploration teams in the issue underlines the interest, application and continuity of research on polar regions by Spanish groups over the last 30 years.

The polar regions have attracted scientific research since the first exploratory expeditions, whose aims included meteorological observations, geological studies and glaciological observations. In the nineteenth and twentieth centuries, the need for geographical knowledge led to an increase in geographical and geological studies as well as searching for natural resources at both poles. But it was undoubtedly since the successive International Polar Years (IPY) and International Geophysical Year (IGY, 1956/57) that a systematic approach was adopted in order that the scientific knowledge could be shared in an effort to improve our understanding of global and local processes. In the first IPY (1882-1883) twelve countries collaborated on simultaneous scientific expeditions to the Arctic (13 expeditions) and the Antarctic ( 2 expeditions), and the basis was established for international scientific cooperation and coordination. In the second IPY (1932-1933), organized by the World Meteorological Organization (WMO), forty nations participated. Research was centred on meteorology, atmosphere and ionospheric phenomena as well as geomagnetism, for which 114 observation stations in the Arctic and the first continental station in the Antarctic were set up. In the IGY (1957-1958), in reality a third IPY, 61 nations took part and a significant advance in the knowledge of the Antarctic continent, the high atmosphere, glaciology, meteorology and seismology was evident. In addition to scientific advances, the IGY led to the 
creation of the Scientific Committee on Antarctic Research (SCAR) and the Antarctic Treaty (1959), enshrining the Antarctic as a continent for science, without ownership and "forever to be used exclusively for peaceful purposes". The fourth IPY (20072008) united once again the efforts of sixty nations with the participation of 50,000 scientists working on key matters such as climate change, geomorphology, geology, oceanography, atmospheric sciences, glaciology, the arctic population, the territory and, for the first time, the teaching and diffusion of the science of the poles and data integration, storage and processing. An overview of the results and organization was published by The International Council for Science (ICSU) and WMO in a document called "Understanding Earth's Polar Challenges: International Polar Year 20072008". The establishment of successive International Years proves that international collaboration and logistic, and scientific and intellectual exchange among research groups and countries is one of the essences of polar research. This allows rapid progress of knowledge and the adoption of collaborative research models. However there are also, no doubt, international problems that arise e.g., the exploitation of natural resources becomes more feasible, or indigenous populations that may be negatively affected by outside interests.

The confirmation that human impact is now the main cause of climate change together with the sensitivity of the high latitudes to these changes has resulted in a considerable scientific concern for the polar environments over the last 25 years. Nowadays there are more than 120 scientific organizations, working groups and national or international institutions orientated towards the study and management of the polar regions, the Arctic, the Antarctic or both. SCAR, formed by 39 nations, and the Arctic Council, in which 9 nations take part, are the most remarkable institutions due to their pre-eminent and coordinating nature.

Polar environments are defined as areas in the North or South Poles as well as surrounding regions in which a person, animal, or plant lives or operates. The polar regions are characterized by the extreme cold winter coinciding with an absence of sunlight for several months of the year, and the presence of extensive areas of ice, mainly in the Antarctic, or by wide ice-free areas favourable to permafrost and periglacial processes, as in the Arctic. Although there are very different polar environments as a result of natural diversity and human settlements, the most significant element of the polar regions is the cryosphere. The term 'cryosphere' refers to the elements of the terrestrial system with water in its solid state, including glaciers, snow cover, ground seasonal ice, permafrost, sea ice, lake ice and ice caves. In terrestrial polar environments the most representative elements are glaciers and permafrost, although the presence of snow cover and lake ice is also important.

Glaciers occupy a broad surface of polar environments, mainly in the southern hemisphere, and they are important on a global scale. The deepest changes in the ice sheets are currently the result of glacial dynamics at the ocean margins. Many glaciers at the margins of the Greenland and Antarctic ice sheets are accelerating their melt processes, and ice losses contribute significantly to global sea-level rise, as it also occurs in the alpine glaciers, as analyzed by Navarro et al. Ice loss is generated by accelerated 
flow, known as dynamic thinning, and nowadays reaches all latitudes in Greenland and is partially intensified in Maritime Antarctica. Glacial flow of over $100 \mathrm{~m} \mathrm{yr}^{-1}$ implies rapid thinning of icefields, with an average rate of $0.84 \mathrm{~m} \mathrm{yr}^{-1}$ in Greenland, and more than $9.0 \mathrm{~m} \mathrm{yr}^{-1}$ in the Amundsen Sea embayment of Antarctica (Pritchard et al., 2009). For 10 years we know that $87 \%$ of marine glacier fronts in the Antarctic Peninsula has retreated over the last 60 years and a clear new boundary further south has been established between the areas with mean advance and mean retreat. The loss of ice at the glacier fronts may imply swifter drainage of the Antarctic Peninsula than was previously thought (Cook et al., 2005). The largest ablation process of the ice-shelf in Antarctica comes from small coves in the Southeast Pacific ice shelves. Ocean thermal forcing may be responsible as well for the main ice melt in Antarctica (Rignot et al., 2013). The total ice loss from Greenland and Antarctica shows a considerable increase in both ice shelves, but in the former this increase has been larger. Since 2000 the ice loss per year in Greenland is almost double that of the Antarctica (Vaughan et al., 2013).

Periglacial environments are defined by cold conditions without glacial processes, and their distinctiveness is the action of frost, seasonally frozen ground or permafrost. Permafrost, defined as the ground that remains at or below $0^{\circ} \mathrm{C}$ for at least two consecutive years, is the main element in the non-glaciated polar areas. The extent of permafrost is much greater in the Arctic, a largely deglaciated environment, than in the Antarctic, a glaciated continent. In the Arctic permafrost warming began two to three decades ago with the greater index at the north of the tree line (Smith et al., 2010; Romanowski et al., 2010). Ground temperature data registered in 350 boreholes and CALM (Circumpolar Active Layer Monitoring) sites, and measurements performed in the western Arctic since the 1970s and eastern Canada since the early 1990s show wide temperature ranges. In the discontinuous permafrost zone, permafrost mean annual ground temperature at most sites is higher than $-2^{\circ} \mathrm{C}$, whereas in the continuous permafrost zone the mean annual ground temperature varies between $-1{ }^{\circ} \mathrm{C}$ and $-15^{\circ} \mathrm{C}$ (Romanowski et al., 2010). The permafrost thermal regime is dominated by latent heat effects in the discontinuous permafrost areas, with ground temperatures close to $0^{\circ} \mathrm{C}$. This allows permafrost environments to persist under warming climates, and reduces the spatial diversity of permafrost thermal conditions in the Arctic (Smith et al., 2010). However, colder permafrost sites are warming more rapidly than permafrost at temperatures close to $0^{\circ} \mathrm{C}$.

In Antarctica, a continent dominated by glaciers, the ice-free areas include very different cold environments. In maritime Antarctica (South Shetland Island and Northern Antarctic Peninsula) permafrost temperatures are slightly below $0^{\circ} \mathrm{C}$ near sea level. During the last several decades the so-called "Dramatic warming of the climate" has taken place, defined by an increase of $3-4^{\circ} \mathrm{C}$ in mean annual air temperature and $6^{\circ} \mathrm{C}$ of mean winter temperature since 1950 (Bockheim et al., 2013).

In the Antarctic Peninsula region, the properties and distribution of permafrost have been deeply influenced by climate warming and permafrost distribution seems to be continuous permafrost $\left(60-61^{\circ} \mathrm{S}\right.$ and $\left.63-65^{\circ} \mathrm{S}\right)$, discontinuous $\left(62-63^{\circ} \mathrm{S}\right)$, sporadic $(64-$ $\left.66^{\circ} \mathrm{S}\right)$, and newly continuous permafrost $\left(71-74^{\circ} \mathrm{S}\right)$. Permafrost temperatures seem to be much lower in continental Antarctica, with cold permafrost on the eastern deglaciated 
mountains occupying slopes recently freed of glaciers, where permafrost changes can be less important than glacial ones (Vieira et al., 2010). Finally, permafrost close to $0^{\circ} \mathrm{C}$ is susceptible to thawing, implying increases in the active-layer thickness, thermokarst features and slope processes such as debris flows or active-layer detachment slides, with significant changes in the geomorphological and soil dynamics (Bockheim et al., 2013). The maritime areas are located in the climatic boundary of permafrost, showing the highest sensitivity to climate change in the region (Vieira et al., 2010, Bockheim et al., 2013).

Snow is a key element and a cryospheric transversal component introducing spatial and temporal complexities and influencing ground and surface waters, physical soil behaviour, biogeochemical flows and the ecosystem dynamics. The presence of snow, unevenly distributed across the landscape due to wind transport in winter and persisting melting in summer, determines many landscape-forming processes. Snow partially determines periglacial processes, ground temperature and runoff regimes. Snow cover and lake ice are determinant in the seasonal freeze ground regime in areas with sporadic or discontinuous permafrost, the active layer dynamic and the hydrological regimes. Finally, the seasonal frozen ground is also a key factor to understand soil and geomorphological processes.

Glaciers, permafrost and snow cover are the key factors in the understanding of terrestrial polar environments and the recent changes generated by natural or human forcing. Deglaciation of land masses in the Antarctic is as recent as the Holocene, whereas the deglaciation of the Arctic happened much earlier and was more complex. In the Antarctic, recent datings reveal that in the Maritime Antarctic the deglaciation of areas now without ice began between 11 and $9 \mathrm{ka}$. Nevertheless, it is well known that in the Arctic, part of eastern Siberia remained free of ice during the Upper Pleistocene. The retreat of the large inlandsis took place $14 \mathrm{ka}$ ago, and the region became entirely deglaciated except for Greenland and the Arctic mountains (Brooke Range, Alaska Range, MacKenzie Mountains, Arctic Cordillera -Baffin, Ellesmere, Osburn Range, Conger Range-, Svalbard, Polar Urals, Verhoyansk and Chersky ranges, Koriaks and Kamchatka) since 4,000 years ago. Broad areas free of ice in which periglacial processes lasted between at least 90 and $10 \mathrm{ka}$, appeared. Since then glaciers have been retreating gradually until present. These changes have taken place in a brief period of time, during the Upper Pleistocene and the Holocene. As a result of global warming processes, there are nowadays areas more sensitive to changes, both in the Arctic and the Antarctic, making the polar environments of particular interest, especially the land cryosphere.

In the polar regions transitions between glacial and periglacial environments have occurred over the last 90,000 years. The long cold nights favour the frozen ground, seasonal or perennial, slow down plant growth and when the cold is extreme the tundra and polar semi-desert become a polar desert dominated by permafrost. Added to these geographical characteristics, the environmental changes superimposed in time and in space generate great spatial and ecological complexity. Nevertheless, the interest lies on the speed of the changes and their variability when changes involve to the cryosphere.

There is a great variety of changes in the cryosphere geosystem, in which five transitional types of environments can be distinguished: glacial to permafrost 
environments (1); glacial to periglacial environments without permafrost and with seasonal frozen ground (2), permafrost to seasonal frozen ground (3); periglacial to cryonival environments (4), and glacial or periglacial to temperate environments (5).

In the Arctic mountains, Greenland and the Antarctic, the processes of change between cryosphere geosystems are defined by the transition from glacial to periglacial environments. The complexity derives from the direction of those changes, either from glacial environment to permafrost environment, common in environments with cold glaciers, or from glacial to periglacial (no permafrost) environment, in which the melt affects temperate glaciers.

Periglacial environments are characterized by the extent of the polar desert, tundra and boreal forest or taiga with sporadic, discontinuous or continuous permafrost, in which the active layer is crucial from an ecological and geomorphological point of view. Towards lower latitudes, changes to seasonal frozen ground environments are brought about by permafrost degradation. Global warming, linked to climatic change, quickly changes the ice-free areas affecting the transitional environments between permafrost and seasonal frozen ground. The degradation of the permafrost frees greenhouse gases such as carbon dioxide $\left(\mathrm{CO}_{2}\right)$ and methane $\left(\mathrm{CH}_{4}\right)$ mainly, which are of planetary importance. Hydrological and geomorphological changes associated with the total or partial melt of the permafrost and changes in the active layer involve important impacts on the territory. Local populations and the exploitation of natural resources must adapt to these changes, including the possibility that new resources might appear (gold deposits in the permafrost, oil, tourism). This is a geographical area exposed to several environmental, social and territorial changes.

Further south, in the lower parts of the polar mountains, periglacial environments as defined by seasonal frozen ground are gradually transformed into cryonival environments, in which the snow cover determines hydrological and geomorphological processes and there is no seasonal freezing, though there are frost cracking processes and freeze/thaw cycles. The environments that determine the lifestyles and adaptation of the Arctic residents to the cold conditions are not as homogeneous as they seem to be. Papers on this special issue of Cuadernos de Investigación Geográfica study glacial environments with significant ice mass losses in Svalbard (Martín Moreno and Allende, Navarro et al.), high latitude periglacial environments of Banks and Prince Patrick Islands (Western Canadian Arctic) and Ross Sea Region of Antarctica (Balks and O'Neill; French), periglacial environments of lower latitudes in Trollalski (Northern Iceland) and South Shetland Island in Antarctica (Andrés et al.; López-Martínez et al.; Molina et al.), and snow and lacustrine environments in Greenland (López-Moreno et al.) and South Shetland Island (Hrbáček et al.).

The Arctic and Antarctic are undergoing very swift changes defined by the degradation of the permafrost and the retreat and thinning of their glaciers. These regions involve a great amount of research on the local, regional and global implications of the changes, not only in natural aspects but also in the societies and people who live and work there, who must adapt to the consequences of recent changes. The study of polar environments contributes at different working levels to an improved understanding 
of our world, its changes and dynamics, in particular of Earth's physical geography at all scales.

\section{References}

Bockheim, J.G., Vieira, G., Ramos, M., López-Martínez, J., Serrano, E., Guglielmin, M., Wihelm, K., Nieuwendam, A. 2013. Climate warming and permafrost dynamics on the Antarctic Peninsula Region. Global and Planetary Change 100, 215-223.

Cook, A.J., Fox, A.J., Vaughan, D.G., Ferrigno, J.G. 2005. Retreating glacier fronts on the Antarctic Peninsula over the past half-century. Science 308, 541-544.

Pritchard, H.D., Arthern, R.J., Vaughan, D.G., Edwards, L.A. 2009. Extensive dynamic thinning on the margins of the Greenland and Antarctic ice sheets. Nature 461, 971-975.

Rignot, E., Jacobs, S., Mouginot, J., Scheuchl, B. 2013. Ice-shelf melting around Antarctica. Science 341, 266-270.

Romanowsky, V.E., Smith, S.L., Christiansen, H. 2010. Permafrost thermal state in the Polar Northern Hemisphere during the International Polar Year 2007-2009: a synthesis. Permafrost and Periglacial Processes 21, 106-116.

Smith, S.L., Romanovsky, V.E., Lewkowicz, A.G., Burn, C.R., Allard, M., Clow, G.D., Yoshikawa, K., Throop, J. 2010. Thermal state of permafrost in North America. A contribution to the International Polar Year. Permafrost and Periglacial Processes 21, 117-135.

Vaughan, D.G., Comiso, J.C., Allison, I., Carrasco, J., Kaser, G., Kwok, R., Mote, P., Murray, T., Paul, F., Ren, J., Rignot, E., Solomina, O., Steffen, K., Zhang, T. 2013. Observations: cryosphere. In T.F. Stocker, D. Qin, G.K. Plattner, M. Tignor, S.K. Allen, J. Boschung, A. Nauels, Y. Xia, V. Bex, P.M. Midgley (eds.), Climate Change 2013: The Physical Science Basis. Cambridge University Press, Cambridge, pp. 317-380.

Vieira, G., Bockheim, J., Guglielmin, M., Balks, M., Andrey, A., Boelhouwers, J., Cannone, N., Ganzer, L., Gilchinsky, D., Goryachkin, S., López-Martínez, J., Meiklejohn, I., Raffi, R., Ramos, M., Schaefer, C., Serrano, E., Simas, F., Sletten, R., Wagner, D. 2010. Thermal state of Antarctic permafrost and active-layer dynamics: Advances during the International Polar Year 2007-2008. Permafrost and Periglacial Processes 21, 182-197. 